Litinfinite Journal

ISSN: 2582-0400 [Online]

CODEN: LITIBR

Vol-1, Issue-1 ( $2^{\text {nd }}$ July, 2019)

Page No: 8-14

DOI: 10.47365/litinfinite.1.1.2019.8-14

Section: Article

\title{
Boundaries of the self: Vignettes of the female gothic in Wuthering Heights and Villette
}

\author{
Dr. Malini Mukherjee \\ Associate professor - Department of English \\ Shri Shikshayatan College, Kolkata, West Bengal, India \\ Mail Id: mmukherjee318@gmail.com
}

\begin{abstract}
The Gothic movement in English literature that started in the eighteenth century thrived on the cult of sentimentalism, sensibility and strong emotions, especially that of fear. Awakening an intensity of consciousness and a new dimension of reality, Gothic established a new relation between the Self and the world. Women novelists and the Gothic have a significant relationship since the genre was at hand for the purpose of expressing the dormant fantasies, forbidden desires and repressed passions, unthinkable to reveal otherwise for the women of the eighteenth and nineteenth century society. Boundaries of the Self and the desire to escape are the two paradoxical facets in Female Gothic during this period. Indeed, a recurring female voice of discontent and suffering amidst confinement and persecution echoes time and again in women's Gothic fiction throughout the eighteenth and nineteenth century. The Self in chains craving for liberty, driven by an urge for transcendence is a common trope in Romanticism; when it comes to women and their predicament, it gains a special significance, since society denied them a notion of authentic Selfhood. The heyday of Gothic romance was also a time when women's place in society was becoming a matter of increasing debate and a number of writers sought to clarify the issue. Most of these attempts to define women's position were also attempts to confine her in a separate sphere bound by the duties of home and to ensure her participation in an ideology that limited the exercise of her physical, intellectual and emotional faculties. In women's writings, this discontent continuously circles around the theme of the boundary of the Self.
\end{abstract}

The genre of the Gothic gives dramatic form to female anxiety of Self.Gothic romance offers a vivid expression of psychological, religious, epistemological and social anxieties that resolve themselves into a concern about the boundaries of the Self. As two of the most intensely passionate voices in English literature, both Emily and Charlotte Bronte express this anxiety in individual ways through their works. My paper will explore the portrayal of the paradoxical theme of constraints and emancipation through the nature and actions of the female protagonists in Wuthering Heights and Villette.

Key Words: Gothic, boundaries, women, passions, anxieties, constraints, transcendence

What were the use of creation if I were entirely contained here- Thus cries the agonised Catherine Earnshaw, trying to voice her desperate urge to move out of her claustrophobic existence and transcend her Self beyond the immediate, in Wuthering Heights. Indeed, a recurring female voice of discontent and suffering amidst confinement and persecution echoes repeatedly in women's gothic fiction throughout the 18th and 19th century. The genre of the gothic gives dramatic form to female anxiety of Self. Gothic romance offers a vivid expression of psychological, religious, epistemological and social 
CODEN: LITIBR

Vol-1, Issue-1 ( $2^{\text {nd }}$ July, 2019)

Page No: 8-14

DOI: 10.47365/litinfinite.1.1.2019.8-14

Section: Article

anxieties that resolve themselves into a concern about boundaries of the Self. The isolated at the heart of the female gothic is one of the many Emilys, Mathildas, Julias and Isabellas, who stand in their very interchangeability, for "Woman "--- the true " separated one " at the heart of the social order.

As two of the most intensely passionate voices in English literature, Emily and Charlotte Brontë express this anxiety through their works. My paper intends to explore the paradoxical portrayal of constraint and emancipation through the nature and activities of the female protagonists in Wuthering Heights and Villette.

The theme of imprisonment takes on a new dimension in women's gothic, exploring women's confinement within the domestic space, their subservient role in the family and regulation by marriage and property laws over which they had no control. All these connect the Gothic with the Domestic, since both are concerned with women's enforced confinement and the paranoid fears it generates. One is reminded of little Jane Eyre's imprisonment in the Red Room and her terrifying initiation into adult sexuality. Jane's illness following her confinement in the Red Room is paralleled in Wuthering Heights by the situation of the tomboy Catherine Earnshaw. Accompanied by her childhood companion Heathcliff at the age of 12, she trespasses on the grounds of Thrushcross Grange, home of the genteel Lintons and is bitten by their watchdog. The Lintons take her in, drive her uncouth companion away and make an un-natural, pampered lady of her. As Bruno Bettelheim observes: "In the world of the fairy tale, the girl's first bleeding is followed by a period of intense passivity in which nothing seems to be happening." (Bettelheim 1976)

The same kind of passive objectification affects Catherine Earnshaw in her passage from adolescence to womanhood, as she is lavished with tender attentions by the Lintons. According to social norms, to be feminine is to appear weak and docile, to be gazed at and not the other way round.

Women's gothic novels are replete with literal and metaphorical imprisonments of wives and daughters. A husband's right to imprison a wife was not challenged legally until 1891 and the gothic villain's concealment of a wife simply enacted in a literal form the laws regarding married women's status.

In Wuthering Heights, Catherine Earnshaw wants to achieve social uplift through marriage. In her passage from Wuthering Heights to Thrushcross Grange, Emily Brontë reverses the sentimental conventions of women's gothic, as it is not in the stormy, dark and grim atmosphere of the Heights, but in the peaceful domestic asylum of Thrushcross Grange that Catherine gets the experience that Mrs. Radcliffe's heroine Adeline goes through in the haunted chamber in The Romance of the Forest, the experience of looking into the mirror and seeing a face other than her own. Against a claustrophobic married life with Edgar, Catherine has only the defence of further self-enclosure, shutting her husband out of her private nightmare in which she ends her life in a fever of transcendent longing, begging that the windows be opened. 
Emily Brontë presents marriage as an imprisonment for women partly because they leave their childhood home to enter the world of their spouse. The theme of feeling " not at home " anywhere but in one's childhood home is prevalent throughout the novel. A pregnant Isabella runs away from the Heights after her harrowing married life with Heathcliff and wants to stay back at the Grange which she considers her "right home "( WH 152 ). Heathcliff imprisons the younger Cathy and forces her to marry his weak and peevish son Linton. The Cathy whom Lockwood observes is effectively a household prisoner, constrained not simply by Heathcliff's brute force, but by contemporary marriage laws and Heathcliff's financial power.

Apart from literal, domestic or marital confinement, women's gothic often shows women's attempts at self-preservation frustrated by the constraint of decorum. Even the impulse to escape physically may have conflict with propriety, which makes Emily St. Aubert staunchly decline her lover's proposal of a secret marriage and elopement on the eve of her fatal transportation to Udolpho. It was only indoors, in Mrs. Radcliffe's day, that the heroine of a novel could travel brave and free, and stay respectable. For them, the mere walking was suspect. Country walking is Jane Austen's principal symbol for the joys of independent womanhood and city walking is Charlotte Brontës sombre evocation of its fears. One does not need to read the scene of Lucy Snowe's late night arrival in Villette to show that city walking is, still today, something different for women than for men. Like chastity or repression, the prison of propriety is as unbreakable as any in female gothic, till Emily Brontë makes Isabella Heathcliff throw away all decorum to the winds in a desperate bid to escape from her abusive husband, " run the whole way from Wuthering Heights " with "nothing on either head or neck " and her feet protected " merely by thin slippers " ( WH 150).

Women's gothic explores another intangible, more impregnable barrier in the way of female transcendence : the self-imposed prison of the reflecting mind. It is Lucy Snowe's insular selfhood that isolates her from the world of Villette and imperils her psychological wellbeing. Lucy's confinement in Mme. Beck's pensionnat is an emblem of her non-existence in the world outside in which her social status is nil. Throughout the novel, Lucy is continually finding herself in places too small for her --- spaces that are assigned to her due to her inferior socio-economic status. She is constrained to shy withdrawal because her lack of an assured place in society allots to her only the position of a mute, almost invisible onlooker.

One of the chief subjects of women's gothic is the vulnerability of women to intrusions from an outside world in the form of assaults on their physical and spiritual selves. It breeds anxiety to make oneself inaccessible to the outside world. This extreme form of selfenclosure often results in neurosis and other associated maladies like hysteria and anorexia nervosa. Published in 1798, Mary Wollestonecraft's Maria or The Wrongs of Woman is the first female gothic novel to use the asylum as a setting. In the 19th century, Robert Carter's study On the Pathology and Treatment of Hysteria (1853) outlines the first systematic theory of repression. Carter argues that the suppression of sexual passion is one of the primary causes of hysteria, and women, both by nature and social convention, are rendered more susceptible than men. Freud describes neurosis as the trauma of surviving a deep psychic wound, and yet being forced to relive it repeatedly in dreams and painful 
memories.(Freud,Vol.x,160).This persistent clinging to misery is what Therese Benedick terms as "negative narcissism".( Spacks, 145). In Wuthering Heights, Catherine Linton wilfully exists in a state of suffering partly because that attracts attention from people around her and defines her exclusiveness (as she thinks ) in their eyes. Catherine embraces her illness as evidence of her distinction --- her sensitive feelings and inability to accept opposition. Confined due to her advanced pregnancy, Catherine starves herself in order to move her husband; by subjugating her body to starvation, she rebels against the conventional identification of women with sex and reproduction. Catherine's masochistic torture on her pregnant body is an extreme manifestation of a fractured self.

In Villette, Lucy Snowe's position as an unmarried woman of ambiguous class drives her to masochistic self-repression; her unprofessed love for Dr. Bretton drives her to "monomania "as she herself admits (V 324 ). " Monomania" was first defined by the 19th century French psychiatrist Esquirol as an "abnormal condition of the physical or moral sensibility, with a circumscribed and fixed delirium".( Esquirol,1965). Alone in the pensionnat, physically and mentally exhausted by the demands made on her by the mentally challenged inmate she has to look after during the long vacation, Lucy suffers a nervous breakdown; her morbid vision turns the empty dormitory into a haunted chamber.

In her isolated confinement in the castle, the manor, the convent or any other patriarchal space, the female protagonist often finds Nature as an ally. As she looks from her room with a view, the gothic heroine's experience of the sublime affords a psychological escape, placing the hostile forces in a perspective that makes them ineffectual in the larger scheme of things. Much in the same manner, after the death of old Mr. Earnshaw and under the authoritative regime of his son, the young Catherine and Heathcliff would defy Hindley's chastisements by escaping on the moors. In an unconscious response to a longing for transcendence, Lucy Snowe is quite literally drawn out of her convent room into an impassioned communion with sublime Nature that in a stormy outbreak, speaks for her inmost Self.

Apart from the solace of Nature, heroines in the female gothic often find succour in the realm of art. The power of the fine arts to overcome boundaries has been acknowledged by Coleridge in his Biographia Literaria where he proclaims:

To make the external internal, the internal external, to make nature thought and thought nature --- this is the mystery of genius in the Fine Arts.

Creating avenues for an extension of the Self, it gives the heroine mental and spiritual strength to endure and resist her isolation and confinement with fortitude. Books provide the ultimate refuge for Cathy Heathcliff in her bizarre confinement at Wuthering Heights where she is tricked into a forced marriage with Linton Heathcliff. If reading a book offers an escape in imagination from oppressive circumstances, writing gives the power of a sovereign gaze. Collecting piecemeal thoughts to give them shape in pen and paper provides the female protagonist with a feeling of exclusive subjectivity, a power denied in real life. Prompted by an urge to move beyond the wall of isolation and imposed silence, heroines like Emily ( The Mysteries of Udolpho ), Adelina and Emmeline ( Emmeline :The Orphan of the Castle ) assert themselves through an introspective gaze in the form of literature and other arts such as lines in verse, melodies, miniature sketches and paintings; on the other hand, Mathilda ( 
CODEN: LITIBR

Vol-1, Issue-1 ( $2^{\text {nd }}$ July, 2019)

Page No: 8-14

DOI: 10.47365/litinfinite.1.1.2019.8-14

Section: Article

Mathilda), Catherine Earnshaw and Lucy Snowe intensify the inward gaze to release their pent-up subjectivity in the form of diary, memoirs and reminiscences.

When Catherine Earnshaw's diary comes up uncannily to the reader's attention, it has the same intrusive effect that the ghostly Catherine of Lockwood's dream has : it breaks the regulations of the narrative scheme, just as a ghost breaks the boundaries of nature. The diary fragment is the only unmediated record of the voice and attitudes of an uninhibited Catherine. Through the dusty pages of her diary, she suddenly erupts within the narrative frame of Wuthering Heights, crossing even the boundary of death, in spite of Lockwood's civilized repulsion for letting her 'in'. Catherine's diary traces the subversive power of her pen for channelling her rebellious desire. For a woman, the control of language through writing provides a counter-phallic power which surreptitiously channels suppressed energies in a more subtle and effective form of subjective assertion. Lucy Snowe's gift of imagination prompts her to write her reminiscences, where she applies an unbiased gaze within herself and towards others. In the process, she breaks up her long silence, and learns to create her authentic Selfhood.

Usurping the power of language is the first step to a process of resistance. The other way is to turn the gaze beyond the familiar realm and start a lonesome journey out of the bounds of domestic enclosure. The basic pattern of the journey myth is the crossing of a threshold from the known, ordinary, everyday world into a fabulous realm of the unknown. In female gothic, this pattern is reworked upon, time and again. In the novels of Ann Radcliffe, this is portrayed in terms of what Ellen Moers calls " travelling heroinism ", adventures of the woman who moves, acts and copes with vicissitude. The fantasy that pervades the female gothic novel is a specifically female quest where the protagonist is guided by a repressed maternal link in the form of an oral culture based on tales, legends, songs and lyrics that run through the novels.

Journey in search of one's authentic identity is a central motif in Villette. The tale of the "black and white nun "( V 135 ), buried alive under an ancient pear tree " for some sin against her vow "( 136 ) is communicated to Lucy by the fellow mistresses in the pensionnat. Thus, the feminine communication process present in these novels seizes the verbal, storytelling, narrative power of the mother, epitomized by Nelly Dean, the presiding female voice in Wuthering Heights. Moonlight also represents for Lucy the spiritual presence of the mother. Throughout Villette, at crucial moments, Lucy is soothed, sustained and even guided by the moon which presides over a final event in her life, when M. Paul Emmanuel gifts her a school of her own. Lucy describes the blessed moment thus:

Above the poplars, the laurels, the cypresses, and the roses, looked up a moon so lovely and so halcyon, the heart trembled under her smile. ( $V 647$ )

The moon that could thus hallow a scene, be a friend, exert a soothing influence, provide strength, suggests in the life of the orphaned protagonist in Villette, a presence of the divine mother. It reminds one that in Mary Shelley's novella, Mathilda's dead mother is "Diana", named after the moon goddess. 
In female gothic, the female protagonist is helped in her quest by women --- wives, daughters and mothers; bonding against male tyranny, this female community encompasses a range of "woman-identified" experience, including the sharing of a rich creative and inner life. In the novels of Mrs. Radcliffe and Eliza Parsons, such as The Mysteries of Udolpho and The Castle of Wolfenbach, the all-female community of the Catholic convent holds a special significance. Women are never happier in these works than when they are living in small groups together and apart from men. Female community or " sisterhood " in women's gothic fiction acts as a confidence booster for the protagonist in her role as a self-seeker. In Villette, Lucy is comforted by Mrs. Bretton, befriended by Paulina Home, vexed and amused by Ginevra Fanshawe on her way to independence.

The obsessive use of boundaries and barriers in female gothic betrays impatience with limits, an impulse away from the constrictions of reason, a desire to move out towards the obscure. This brings in the concept of transgression, the most audacious form of gazing beyond, in the quest for Self. Transgression tells the story of journeys that fail to work. The threshold between the familiar and the unfamiliar is crossed, and the experience is such that it renders a return to the familiar world meaningless or impossible. In Charlotte Dacre's Zofloya, the protagonist Victoria, driven by a violent and undaunted Self-seeking, rejects the limits imposed upon the "human" by bartering her soul to Satan in a conscious deal; she lives out the logic of her own quest for Selfhood in the final liberty of death. In Mary Shelley's Mathilda, the protagonist's sense of identity lies in her own fixation with her fears and desires and her willingness to embrace death as a final remedy. In Wuthering Heights, Catherine desperately resists her identity of tamed domesticity and motherhood. Her desperate urge to move beyond her enclosure drives her literally, in the words of Nelly Dean, to " catch her death " by throwing open the window. To escape the boundaries of the Self in the way Catherine and Heathcliff desire is to rebel against the human condition itself. The fact that Heathcliff's eyes refuse to close in death suggests a demonic assertion of Self in defiance of God, deliberately transgressing the limits of mortality.

Even if society forces the woman to assume the invisible position of ghostliness, as a silenced voice and an elusive presence --- the space of narrative which she occupies draws her into an eloquent discourse of death. Years back, Signora Laurentini had been cloistered in the convent and died there; yet her invisible presence in tales, anecdotes and mysterious music haunts the atmosphere in The Mysteries of Udolpho. The burning eyes of the buried nun stalk Lucy Snowe in her hallucinations till she exorcises the presence out of her own self and out of Villette by destroying the effigy of the nun on her bed, getting rid of her masochistic repression of desire in the process. Dead and buried, Catherine yet swarms the air with her presence in the enclosure of her panelled bed in Wuthering Heights, where her name is repeated " in all kinds of characters, large and small --- Catherine Earnshaw, here and there varied to Catherine Heathcliff, and then again to Catherine Linton" ( WH 32 ). The disruptive resurgence of such female presence, standing for lost desire, haunts these novels, till the female protagonist re-searches and re- covers this loss through an assertion of her mature vision of Selfhood. 
Litinfinite Journal

ISSN: 2582-0400 [Online]

CODEN: LITIBR

Vol-1, Issue-1 ( $2^{\text {nd }}$ July, 2019)

Page No: 8-14

DOI: 10.47365/litinfinite.1.1.2019.8-14

Section: Article

\section{Works cited}

\section{Primary Texts:}
i. $\quad$ Brontë, Emily. Wuthering Heights, 1847. Kolkata : Rupa \& Co., 1977.
ii. Brontë, Charlotte. Villette, 1853. Hertfordshire : Wordsworth Editions Ltd., 1993.
iii. $\quad$---------one Eyre, 1847. New Delhi : Rupa \& Co., 2001.

\section{Other References:}
i. $\quad$ Bettelheim, Bruno. The Uses of Enchantment. New York : Alfred A. Knopf, 1976.
ii. DeLamotte, Eugenia C. Perils of the Night : A Feminist Study of Nineteenth Century Gothic. London : O.U.P., 1990.
iii. Esquirol, J.E.D. Mental Maladies : A Treatise on Insanity. Trans. E.K. Hunt. New York, 1965.
iv. Freud, Sigmund. The Standard Edition of the Complete Psychological Works of Sigmund Freud. Trans. James Strachey. London : Hogarth Press, 1961. Vol.x.
v. $\quad$ Moers, Ellen. Literary Women. New York: Anchor Books, 1977.
vi. $\quad$ Spacks, Patricia M. The Female Imagination. London : Allen \& Unwin Ltd., 1976. 